\title{
TEF - Tiresomely Extraneous \& Flawed?
}

\author{
James Derounian
}

The Teaching Excellence Framework (TEF) is incoming. National Teaching Fellow, JD, reads the runes.

As the Times Higher Education (2016) put it, the "teaching excellence framework will see the government monitoring and assessing the quality of teaching in England's universities." Good. It is high time that teaching excellence and research excellence were given parity of scrutiny, importance and reward. As I argued in 2015: "Let's start with the bottom line - the money. What is it that contributes in the main to university coffers? THE IMPACT OF UNIVERSITIES ON THE UK ECONOMY, from Universities UK, elevates teaching income 2011-12 over that from research: with tuition fees, education grants and contracts accounting for $35 \%$ of university income, whilst research generated just 16\%" (Derounian, 2015).

And the UK Government's 2016 TEF Factsheet asserts, at the start: "Teaching excellence matters - not only for students and taxpayers, but also for social mobility - helping to address inequality by allowing students to fulfil their aspirations and progress onto their chosen careers." Well said. And quite right that higher education providers should be accountable, to paying students and taxpayers. Quite right too, that qualifications should be available and attainable for individuals regardless of background; and lead them towards fulfilling lives and work.

But what lies beneath? And what we discover is a mass of uncertainties. This is even more concerning given that, apparently, the latest version of the TEF "reflects the decisions made by the Government in response to the Technical Consultation" (DfE, 2016: 5). What it all boils down to is that $\mathrm{HE}$ institutions will be initially rated - rather like the Olympics - Bronze, Silver and Gold. TEF assessors will be "either experts in teaching and learning in a higher education setting, or students. Their role is to assess TEF applications and agree provisional outcomes" (ibid, 2016: 52). It's then down to a panel - similarly made up of teaching and learning experts, students and employers - to agree the final TEF ratings. English universities "achieving a rating of Bronze, Silver and Gold will receive the full inflationary uplift": so, they will be able to charge tuition fees of $£ 9,250$ per head (ibid, 2016: 6). But how, with any certainty, can you rate an entire university - administration, admissions, student support, different departments and 


\section{TEF Special Edition}

disciplines - and reduce it to a single word - Gold, Frankincense, Silver or, heaven forfend, Bronze? Pity (all) universities with fantastic teaching departments (let's say Medicine, Earth Science), but also some middling ones (hypothetically, English and Sports Development) and bad bits (e.g. Biology and Economics) ... what does an overall medal for a 1st, 2nd or 3rd place signify? Yet Government sets down that assessors "will be looking for evidence of how far a provider demonstrates teaching and learning excellence across its entire provision." (ibid, 2016: 36; my underlining). And how - in the first phase - will this blunt assessment "provide better information for students to support them in making informed choices"? Given an overall 'medal', how exactly will this help prospective students to choose where to study their particular preferred course?

There are positives, however, in terms of Government's recognising that a subsequent "move to subject level will be informed by a series of pilots in Year Three to test the assessment framework and process at subject level." (ibid, 2016: 6). As with undergraduate dissertations, so with high policy: smaller-scale piloting and experimentation, accompanied by evaluation, potentially offers safer passage for whatever evolves. The TEF begins with undergraduate provision but will, from Year Four, take in postgraduate assessment as well. And (ibid, 2016: 37) - all to the good - "providers are encouraged to show how they have involved students in preparing the submission." So, although I personally don't relish the prospect that "TEF awards given in Year Two will be valid for three years (subject to a provider continuing to meet eligibility requirements)", this seems fair enough in terms of accountability, currency and enabling students to make better informed choices about universities, departments, and the quality of their provision. And I look forward with relish to HE sector institutional culture that "facilitates, recognises and rewards excellent teaching" (ibid, 2016: 21).

On the downside, the Framework links wonderful teaching to students' securing professional jobs. Student Outcomes is one of the measures set down in the TEF and, in particular, employment/further study data plus the more focused graduation into highly-skilled employment/further study (from DLHE, Destinations of Leavers from Higher Education, returns). But what planet is Government on, when the DLHE first destination job census takes place just six months post graduation? A year on would, surely, give graduates at least a fighting chance of moving into (meaningful) jobs? Furthermore, what has terrific teaching got to do with job attainment? We lecturers can give our students employability skills - priming them with quality teaching experiences, real-world learning, internships - but we cannot guarantee them decent jobs; there are too many other variables (such as individual personality, commitment, 


\section{TEF Special Edition}

enthusiasm, aptitude) that will persuade an employer to employ a graduate... or not. And what about the general state of the (global) economy? If there is a recession, or jobs are scarce and Government is reducing state funding, then, with the best will in the world, university teachers cannot conjure up "highly skilled employment" for graduates (ibid, 2016: 22). Gold, for example, requires that "the provider achieves consistently outstanding outcomes for its students from all backgrounds, in particular with regards to retention and progression to highly skilled employment and further study." (ibid, 2016: 46). So, how does that square with the distance travelled by an individual? That is another TEF criterion. For example, an HND may be a tremendous outcome for a student and demonstrate impressive development and progress, but yet not lead to further study or professional employment. What then? Is that deemed a success, or a sub-degree failure? It's hard to see how achievement of professional jobs (as one criterion) squares with another measure, namely learning "gain and distance-travelled by all students including those entering higher education part-way through their professional lives" (ibid, 2016: 39). It is also uncertain whether the institutional medal awards will run in parallel with subject medals, or whether the whole-university judgement will be superseded by course-level gongs. Interestingly, the "Devolved Administrations have confirmed they are content for providers in Wales, Northern Ireland and Scotland to take part in Year Two, should they wish to do so" (ibid, 2016: 18). What if they don't "wish to do so"? Furthermore, how exactly does "a commitment to widening access and participation" link to teaching excellence (ibid, 2016: 12)?

And, taking a broader view, Dr. Joshua Forstenzer at the University of Sheffield rightly points out that the "TEF ought to reflect higher education's full range of social purposes". It's not just about the economy, or material gain. Michael Oakeshott, (1950: 30) discussing The idea of a university, specifically warns that "a university needs to beware of the patronage of this world, or it will find that it has sold its birthright for a mess of potage". Oakeshott continues, a "University will have ceased to exist when its learning has degenerated....and when those who came to be taught come, not in search of their intellectual fortune but....desire only a qualification for earning a living or a certificate to let them in on the exploitation of the world." Where are student wellbeing and the idea of universities' contributing to the growth of decent, compassionate, giving human beings?

So what lies beneath? Brexit, for example, represents something of an iceberg - large and still hidden in swirling mist, yet potentially damaging to UK student teaching and learning: departing the EU jeopardises a range of collaborations and research projects including the European 


\section{TEF Special Edition}

Union's Horizon 2020 programme and the ERASMUS student exchange scheme. Universities, unsurprisingly, are worried. (The Conversation, 2016 online).

Patrick McGhee, Assistant Vice Chancellor at the University of Bolton, brings this down to impacts on individual students and believes that "we can surely do better than finding the best teaching, and then increasing the prospective debt of the young people who might benefit most from that teaching."

\section{Reference list}

Adams, R. (2016) 'English universities to be ranked gold, silver and bronze.' Guardian. Available at: https://www.theguardian.com/education/2016/sep/29/english-universities-rankedgold-silver-and-bronze (Accessed: 7 October 2016).

Coman, J. (2016) 'Value for Money can't be the only measure of university.' Observer, 21 August 2016, p. 37.

Derounian, J. (2015) 'Why does the devil have all the good tunes? How researchers continue to put one over teachers in the HE promotion stakes.' British Educational Research Association, 5 May. Available at: https://www.bera.ac.uk/blog/why-does-the-devil-have-all-the-good-tunes-howresearchers-continue-to-put-one-over-teachers-in-the-he-promotion-stakes (Accessed: 7 October 2016).

Forstenzer, J. (Undated) The Teaching Excellence Framework: What's The Purpose? Available at: http://www.crickcentre.org/wp-content/uploads/2016/01/TEF-Whats-the-Purpose-bookletJosh-Forstenzer.pdf (Accessed: 7 October 2016).

HM Government, Department for Education (2016) Policy paper: TEF Factsheet. Available at: https://www.gov.uk/government/uploads/system/uploads/attachment_data/file/550232/Teaching -excellence-framework-factsheet.pdf (Accessed 7 October 2016).

HM Government, Department for Education (2016) Teaching Excellence Framework: year two specification. Available at:

https://www.gov.uk/government/uploads/system/uploads/attachment_data/file/556355/TEF_Yea r_2_specification.pdf (Accessed: 25 November 2016). 


\section{TEF Special Edition}

House of Commons, Business, Innovation and Skills Committee (2016) The Teaching Excellence Framework: Assessing quality in Higher Education. Available at:

http://www.publications.parliament.uk/pa/cm201516/cmselect/cmbis/572/572.pdf (Accessed: 7 October 2016).

McGhee, P. (2016) 'Will the Teaching Excellence Framework be a licence for universities to raise fees?' Independent, 22 August 2016. Available at:

https://www.theguardian.com/education/2016/aug/22/teaching-excellence-frameworkuniversities-tuition-fees-tef (Accessed: 10 October 2016).

Oakeshott, M. (1950) 'The idea of a university.' Listener, 23-30. Available at:

https://www.msudenver.edu/media/content/facultyevaltaskforce/sources/oakeshotttheideaofauni versity.pdf (Accessed: 8 October 2016).

The Conversation (2016) 'Insularity is not the way forward': three university vice-chancellors on Brexit, Available at: https://theconversation.com/insularity-is-not-the-way-forward-threeuniversity-vice-chancellors-on-brexit-60660 (Accessed: 7 October 2016).

Times Higher Education (2016) Teaching excellence framework (TEF): everything you need to know. 4 August 2015. Available at: https://www.timeshighereducation.com/news/teachingexcellence-framework-tef-everything-you-need-to-know (Accessed: 7 October 2016).

Universities UK (2014) The Impact Of Universities On The UK Economy. Available at: http://www.universitiesuk.ac.uk/highereducation/Documents/2014/ThelmpactOfUniversitiesOnT heUkEconomy (Accessed: 7 October 2016).

Williams, K. (1989) 'The Gift Of An Interval: Michael Oakeshott's Idea Of A University Education.' British Journal of Education Studies, XXXVII(4), 384-397, November. Available at: https://www.jstor.org/stable/3121347?seq=1\#fndtn-page_scan_tab_contents (Accessed: 7 October 2016). 